\title{
Etymology and
}

\section{Meaning of}

\section{проaipgors in}

\section{Aristotle's Ethics}

MACIEJ SMOLAK

Institute of Philosophy

Department of Ethics

Jagiellonian University

Grodzka 52

33332 Cracow

Poland

m.smolak@iphils.uj.edu.pl

\section{ABSTRACT}

Abstract: In NE III.2 1112a13 Aristotle raises the following question: "What

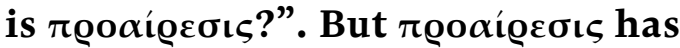
different meanings and it is practically untranslatable into modern languages, as are most crucial terms of classical Greek. In this article, the author

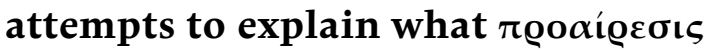
is for Aristotle. The author first presents the etymology of the term

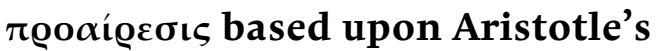
remarks in his ethical treatises and shows that the term does not reflect

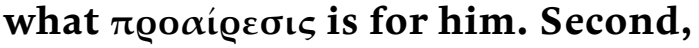
the author outlines characteristics of the uncontrolled person and indicates, on this ground, what Aristotle's

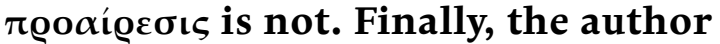

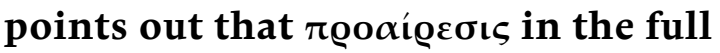
sense involves two elements - the orectical-deliberative element and the decisional-functional element - and sketches out their features. 


\section{INTRODUCTION}

In NE III.2 1112a13 Aristotle raises the following question: "What is

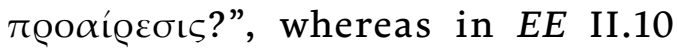
1225b19-20, he notes that one might be in doubt about the genus to which

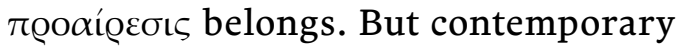
commentators have bigger doubts as to

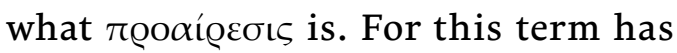
several meanings ${ }^{1}$ and it is practically untranslatable into modern languages, as are most crucial terms of classical

1 The term прохіргбıs occurs in different contexts and may mean, for example, "choice", “decision", “purpose”, “under-

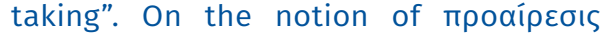
and the number of appearances of it in Greek writing or language, see Gauthier and Jolif (in Aristotle (1959), pp. 189-190). See also Formichelli (2009), pp. 21-32 who additionally presents the occurrence of проаірєбıs in the Aristotelian Corpus.
Greek $^{2}$. However, it does not mean that

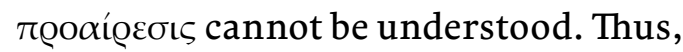
an attempt at interpreting Aristotle's

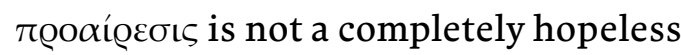
task. Nonetheless, one must be careful not to be tempted to replace $\pi \varrho 0 \alpha i ́ \varrho \varepsilon \sigma \iota \varsigma$ with one word or to narrow its many

It should be noted that the main Greek terms are in principle untranslatable into

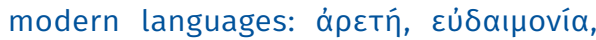

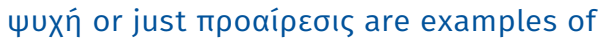
such terms. This is due to the fact that they occur in a different and temporally distant cultural reality. The practice of using a one-word equivalent for the Greek notion is essentially an obstacle to becoming acquainted with semantic variability of it in different contexts. Thus, some commentators think that basic Greek terms should be left in transliteration or in Greek font and they ought to be treated as tool words with different meanings, see e.g., Adkins (1972), p. 4. 
meanings down to only one ${ }^{3}$. That is why I will not translate this term throughout the paper and leave it in the original version ${ }^{4}$.

This article consists of three sections. In the first section, I present the

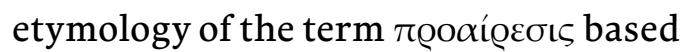
upon Aristotle's remarks in his ethical treatises and show that etymological

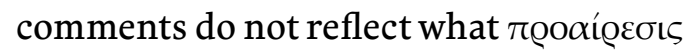
is for Aristotle himself.

In the second section, I refer to the passage NE VII.10 1152a15-24 in which Aristotle claims, among others things,

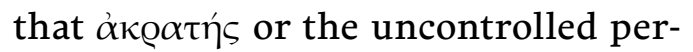

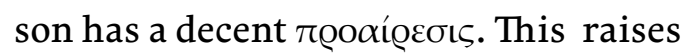
a question, because he insists in another

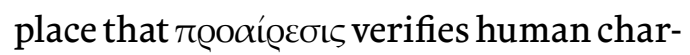
acters better than actions (III.2 1111b6) Thus, there is the following puzzle: If

See e.g., Nielsen (2011), p. 385, note 6)

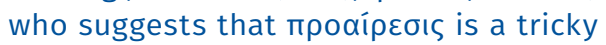
term.

4

Commentators differently translate the

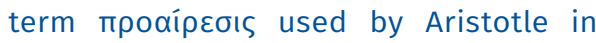
Ethics. See e.g., Aquinas, Thomas (in Aristoteles (1949)) - electio; Irwin (in Aristotle (1985)) - decision; Crisp (in Aristotle (2000)) - rational choice; Dirlmeier (in Aristoteles (1962)) - Entscheidung; Gauthier i Jolif (in Aristote (1958)) - décision; Gromska (in Arystoteles (1956)) - postanowienie (in English - resolution); Kenny (1979) - purposive choice or choice; Ostwald (in Aristotle (1962)) - choice, but see also Glossary - choice, or moral choice; Sorabji (1980) - deliberative choice; Tricot (in Aristote (1959)) - choix préférentiel; Wróblewski (in Arystoteles (1977)) - postanowienie, czyli świadomy wybór (in English - resolution, that is, conscious choice); Zanatta (in Aristoteles (2012)) scelta deliberata.

5 Cf. EE II.11 1228a2-3 and 1228a11; but see also 1228a15-17: "Furthermore, it is because it is not easy to discern what

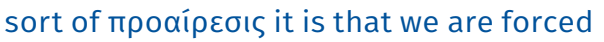

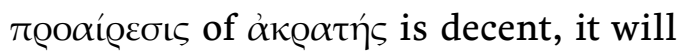
be a problem to distinguish between the character of the uncontrolled person and the character of the decent person or the serious one. Therefore, I outline features of the uncontrolled person, especially, of the melancholic and weak one. Next, I consider an example of an uncontrolled behavior that can be useful for under-

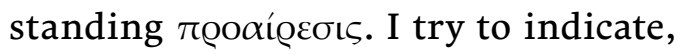

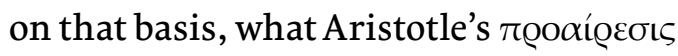
is not. I put forward a suggestion that

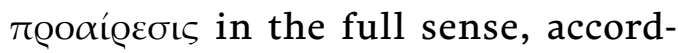
ing to Aristotle, is none of the things included in a list of features, nor their

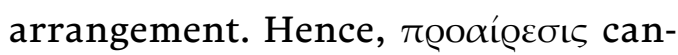
not be reduced to any of these features: setting a goal nor to thoughtful undertaking nor to preferential choice, i.e., choice of one course of action rather than another, nor to deciding about proceeding with the realization of a thoughtful undertaking or a preferentially chosen course of action nor to deciding about proceeding with what is chronologically first in the sequence of steps which lead to reaching the set goal. At all events,

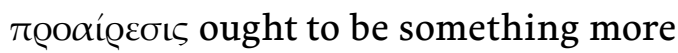
than the configuration of them, that is, if

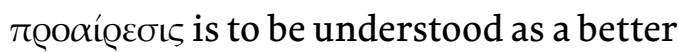
verifier of human characters than actions.

In the third section, I attempt to

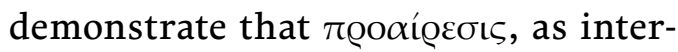
preted by Aristotle, consists of two elements - the orectical-deliberative element and the decisional-functional element - and I try to sketch out their features.

to verify from the deeds what sort of person someone is". 


\section{THE ETYMOLOGY OF THE TERM MPOA'IPEEIE IN ARISTOTLE'S ETHICS}

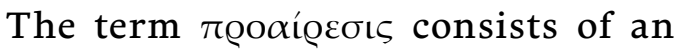

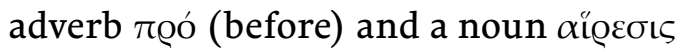
(choosing or taking, seizing, grasping with the hand). Literally, it means "choosing one thing before another" or "taking one thing before another". The adverb roó, however, can be understood preferentially or temporally ${ }^{6}$.

The first interpretation would sug-

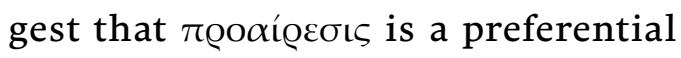
choice, i.e. a choice of one thing in preference to another or a choice of one course of action in preference to an-

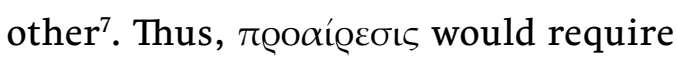
a comparison of alternatives.

In the case of the second interpretation the point can be understood in two ways: a] the adverb roó can underline the point that rooxípeors is made on the basis of deliberation that is prior to action $^{8}$ - temporal as "before the action"; b] the adverb r@ó can stresses the point

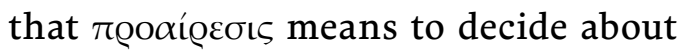

6 See e.g., Brown (in Aristotle (2009), p. 220) who maintains that the adverb про́ - in

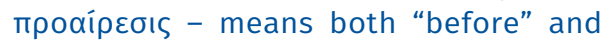
"in preference to". However, she suggests that the first meaning emphasizes what happened before the action. She says that "choice is of one course of action rather than another, but it also [...] is what has been decided by an earlier deliberation (i.e. before the action)".

7 The partisan of preferential understanding of the adverb про is, e.g., Aquinas, Thomas (1949), p. 128.

8 The partisan of the first temporal understanding of the adverb про is e.g., Irwin (1999) who points out in his comment to NE III.2 1112a15-17 that "what is decided is what has been previously deliberated (to probebouleumenon)". doing what is chronologically first in the deliberated sequence of steps which lead to achieving the set goal ${ }^{9}-$ temporal as "first in action".

However, it must be added that there is another understanding of the adverb ז९ó. It is underlined by Nielsen ([2011]: 408) that the preferential and temporal understanding are not exhaustive. The adverb roó can emphasize that the agent picks out the act for the sake of a specific goal and takes the position in front of it with the purpose to defend $\mathrm{it}^{10}$. Thus,

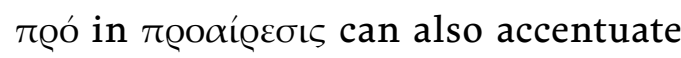
the idea that the agent is about to protect a certain goal in order to achieve it $^{11}$. What, however, does Aristotle himself say about the etymology of the term

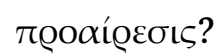

In $E E$ II.10 1226b2-8 - after empha-

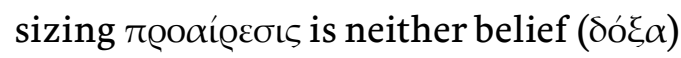
nor wanting $(\beta o u ́ \lambda \eta \sigma \iota \varsigma)^{12}-$ Aristotle

9 The partisan of the second temporal understanding of the adverb про́ is e.g., Joachim (1955), pp. 100-101.

10 'This is a use of 'pro' that is evident in expression such as 'stēnai pro Trōōn': standing in front of, and hence in defense of, the Trojans. Latin uses 'pro' in a similar sense in expressions such as 'pro bono' (an abbreviation of 'pro bono publico', for the common good)", Nielsen (2011), p. 408, note 39. See also Bostock (2000), p. 39, note 21 who insists that “"choice-for-the-sake-of', i.e., a choice made with some definite end in view" fits

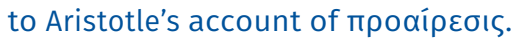

11 Nielsen (ibidem), p. 408 thinks that Aristotle wants us to hear all three senses

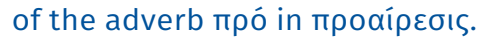

12 A few lines earlier Aristotle excludes

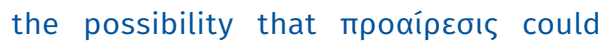

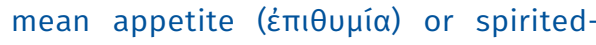

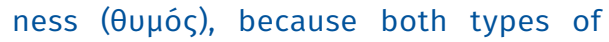
desire are typical for animals, whereas проаiрعбıs does not occur in animals (EE 


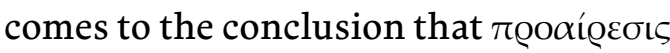
is the result of the combination of both these things. For they are present dur-

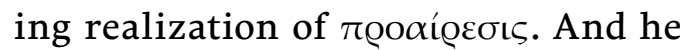
underlines that it is also shown, if only

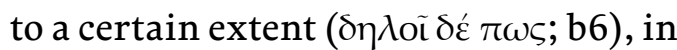
the name itself for " $\pi \varrho 0 \alpha i ́ \varrho \varepsilon \sigma \iota \varsigma$ is choosing/taking; not simply, but one thing before another, and this is not possible without examination and deliberation.

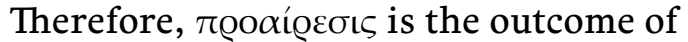
deliberative belief"13.

In NE III.2 1112a13-17 - after un-

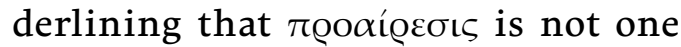
of the things discussed before, i.e.

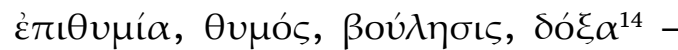

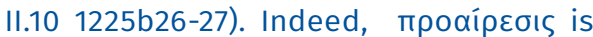
a distinct feature of human beings. And probably for this reason too, Aristotle

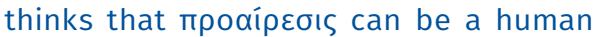
trait on the basis of which people's characters are better fixed.

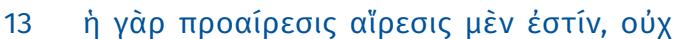

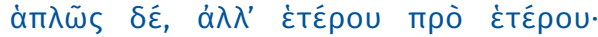

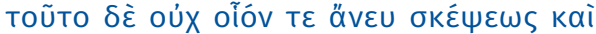

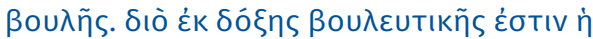

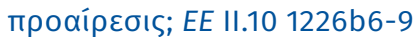

14 In both Ethics Aristotle indicates certain

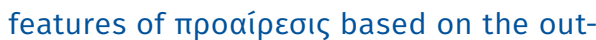

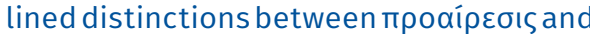
four other phenomena of $\Psi \cup x \bar{n}$, namely

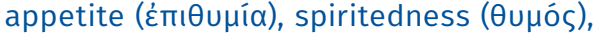

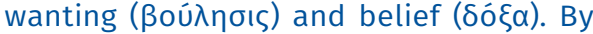

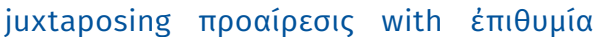

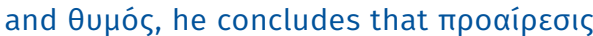
concerns the "good" or "bad", whereas

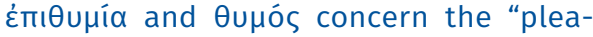
sure" or "pain". Against the background of

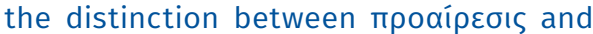

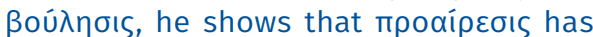
only to deal with things that depend on

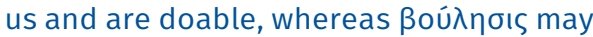
also refer to things that do not depend on us and are not doable. In turn, when it comes to the discrepancy between

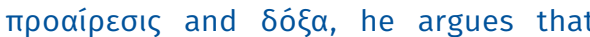

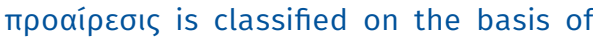
whether it is good or bad, whereas $\delta$ ó $\xi a$ is classified on the basis of whether it is
Aristotle poses the question whether

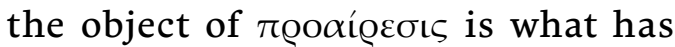
been obtained by prior deliberation ( tion seems rhetorical, as Aristotle adds " $\pi \varrho o \alpha i ́ \rho \varepsilon \sigma \iota \varsigma$ is connected with calculation and thought - and even the name appears to signify that the object of

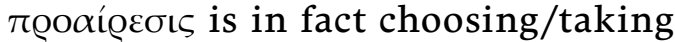
before another"15.

In $M M^{16}$ I.17 - after underscoring that

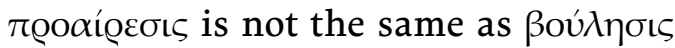
(1189a12-13) ${ }^{17}$ - the Author states that

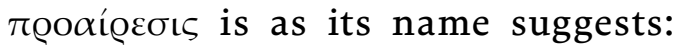
"Therefore, whenever we take the better in exchange for the worse - when it is a mat-

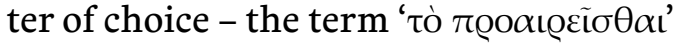
would seem to be correctly used" 18 .

true or false (see EE II.10 1225b26-1226b2 and NE III.2 1111b12-1112a11).

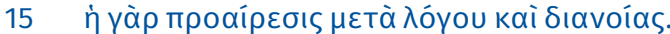

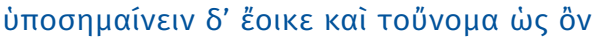

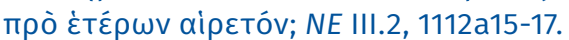

There are disputes as to the authenticity of the $M M$. Some commentators argue that $M M$ is the work of Aristotle (see e.g. Schleiermacher (1835), Düring (1966)). Others claim it is not (see e.g. Jaeger (1923), Kenny (1978). Bobonich (2006) remarks that some ethical analyses in $M M$ differ from analogical analyses in $E E$ and $N E$. And this is - in my opinion - the case with etymology of mpoaipeoıs. For in $M M$ the explanation is founded on the preposition ávTí, while in EE and NE it is founded on the adverb про́ (see, however, note. 19).

17 A few lines earlier the author of $M M$ declares that проаiрعбıs is not desire

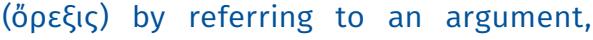
which is analogical to the argument in $E E$ (see note 12). But there is a difference, for

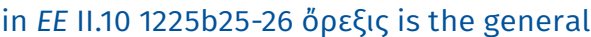
term for three types of desires, i.e., appetite, spiritedness and wanting, while in

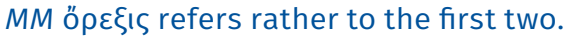

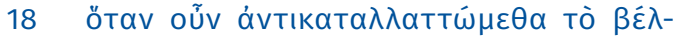

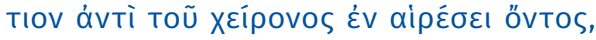


Etymological notes do not exclude preferential nor temporal meanings of the adverb זœó ${ }^{19}$. But Aristotle clearly emphasizes that $\pi \varrho o \alpha i ́ \varrho \varepsilon \sigma \iota \varsigma$ remains in close relation with calculation and thought ${ }^{20}$. So, there are reasons to assume that the adverb זœó refers pri-

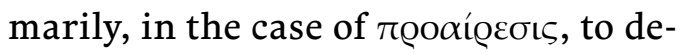

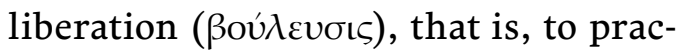
tical thought which precedes an action that ought to lead to achievement of a set goal. Indeed, the deliberation consists in discovering and developing a reliable way to the realization of the established goal. However, it does not follow that

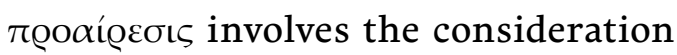
of alternatives and choosing only one of them.

In NE III.3, where Aristotle studies deliberation, it is shown that it is a search which relies on finding the means needed to achieve the designated

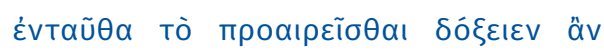
oíkعĩov عĩvaı; MM I.17 1189a14-17.

19 In $M M$ the adverb про́ appears in 1.17 1189a34, where the author points out an inseparable connection between

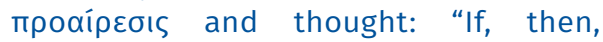

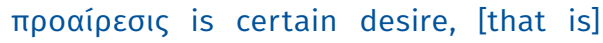
determined by deliberation, [that is] acompanied with thought (Ei Toívuv ì

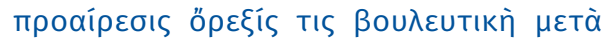

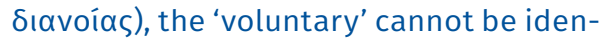
tical with 'проаıрето́v'. For we do many things voluntarily before thinking and

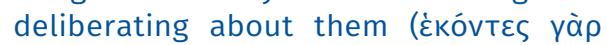

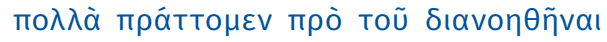

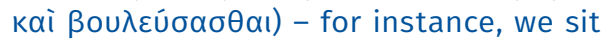
down and stand up, and do many other things like that voluntarily but without having thought about them - whereas each action taken in accordance with

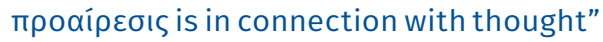
(1189a32-1189b1).

20 On the matter of close relation between

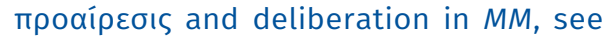
note 19 . goal. It is true that he permits situations in which a given goal can be achieved in many ways. Then, in such circumstances, the task of deliberation is, first of all, to find the easiest and finest way to do so (1112b17). In this sense,

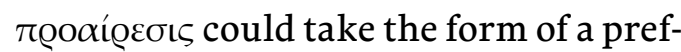
erential choice and to be a choice of one of several alternatives that have been previously considered. But it does not follow that it must be so and thus, that a preferential choice is the constitutive

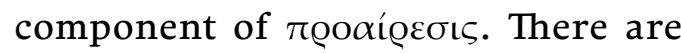
also situations in which the established goal can be achieved through only one means. In such circumstances, the task of deliberation is to consider how it will come about through this means and how this one can be obtained (b17-18).

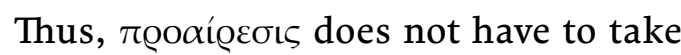
the form of a preferential choice. It does not have to be "choice of one thing in preference to another or of one course of action in preference to another". What

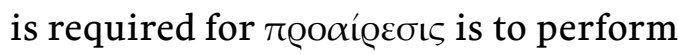
some sort of intellectual work, that is to make an investigation combined with

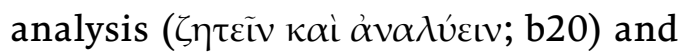

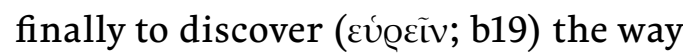
that guarantees the accomplishment of designated goal. But it is necessary to add that the process of seeking may be successfully completed, when such a way is possible at all and the discovered way is possible for the person who was looking for it.

Thus, the preferential interpretation of the adverb rœó can be misleading.

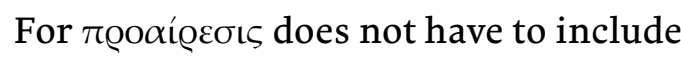
the choice of one thing in preference to another. In this sense, the temporal 
interpretation of the adverb rœó is more promising, because $\pi$ @ó can stress that a thoughtful undertaking has come into

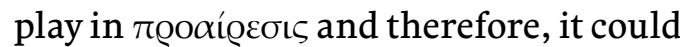
simply be taking on something after prior deliberation. However, it may well suggest that it is about taking on something that was indicated by deliberation as chronologically first in the sequence of steps which lead to the achievement of the goal laid down.

The temporal interpretation of the adverb тœó seems to be confirmed by the summary note of III.3. Aristotle

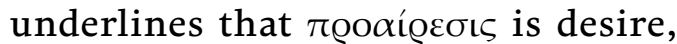
determined by deliberation, for something that is up to us ${ }^{21}$. The statement draws attention to the connection of

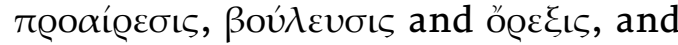
it is also important because of this connection. However, it does not follow that it is impossible to maintain the preferential interpretation of the adverb roó. Rather, the point is that the application of the adverb roó is not limited to its preferential understanding. Thus, given situations in which various alternatives of action must be considered, it may be suggested that in some contexts the preferential understanding of the adverb Toó is not wrong.

However, it must be added that Aristotle introduces his etymological remarks using phrases ${ }^{22}$ that seem to suggest that the explanation of the ori-

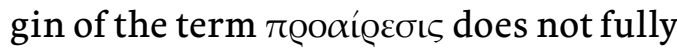

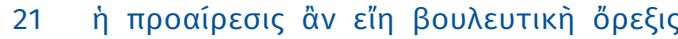

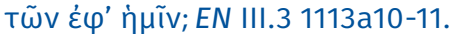

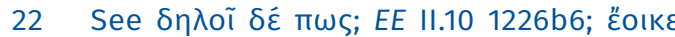

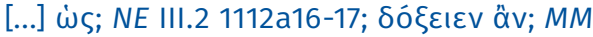
I.17 1189a17. reflect what it is for him. Admittedly, the Greek term does not reflect the relation between deliberation and desire in real-

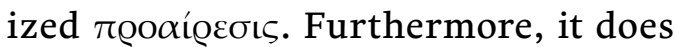
not indicate the connection between

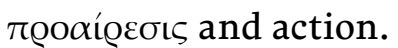

Let's repeat again, Aristotle under-

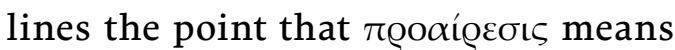
desire qualified by deliberation

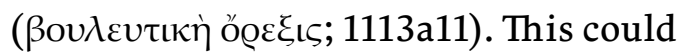

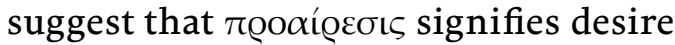
which has gained an imprimatur of reason $^{23}$. Hence, it becomes a real desire to achieve a goal in accordance with an algorithm elaborated in the framework of deliberation. After all, wanting a goal is equivalent to wanting reliable means to achieve it, but only those that are in our power.

I think, however, that Aristotle is interested in something more. I will try to demonstrate that Aristotle's

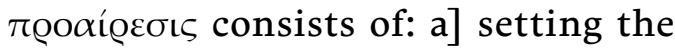
goal; b] thoughtful undertaking or preferential choice, where both assume deliberation about how to achieve the designated goal but second requires

See e.g., Charles (2011), p 204 who suggests that проаiрвбıs ('preferential choice' in his translation) is not "a combination of intellect and desire but rather a distinctive type of state: intellectual desire or desiderative intellect". It could be added that in EE II.10 1225b20 Aristotle raises the following question:

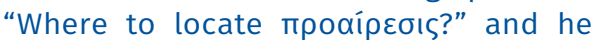
does not answer this question. In NE he does not even pose a similar question.

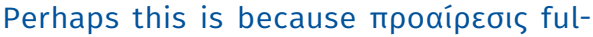
fills the function of the link which merges the rational and irrational dimension of чuxদ́ into a harmonious whole. Thus, it is difficult to formulate an unambiguous answer to the question "Where to locate

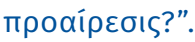


deliberation on alternative courses of action; c] making the decision about proceeding with a thoughtful undertaking or preferentially chosen course of action; d) proceeding with the realization of the determined course of action, that is, taking on what has been determined by deliberation as chronologically first in the sequence of steps that lead to the achievement of the designated goal; e] continuation of action that leads to the achievement of that goal. Thus,

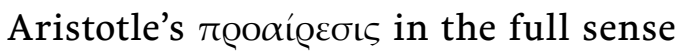
ought to contain these five moments or features. This claim can be shown

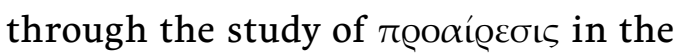
case of the uncontrolled person.

\section{THE UNCONTROLLED PERSON AND IPOA'IPEEIE}

In NE VII.7 1150b19-28 Aristotle shows two basic kinds of uncontrolled person: the impetuous uncontrolled per-

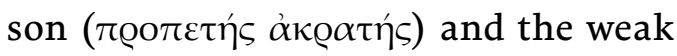

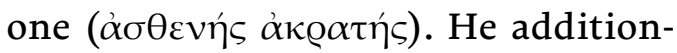
ally distinguishes within the first type the melancholic uncontrolled person ( $\mu \varepsilon \lambda \alpha \gamma \chi 0 \lambda \iota \kappa o ́ \varsigma \alpha \alpha \kappa \varrho \alpha \tau \mid \varsigma)$ and the swift

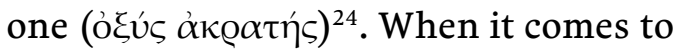

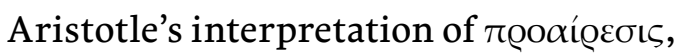
it is NE VII.10 1152a15-20 that deserves attention:

"So the uncontrolled person is not like those who know and have regard for their knowledge, but like those who are asleep or drunk. Although they act voluntarily - for they know in a way

24

On the matter of typology of uncontrolled persons, see e.g. Charles (2011), pp. 187-209. both what they are doing and for the sake of what they are doing it - they are

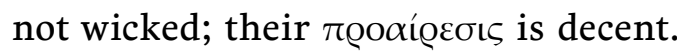
As a consequence, they are only halfwicked. They are not unjust either, since they do not draw up an action plan of their bad deeds. One type of the uncontrolled person is not apt to abide by the results of their deliberation, while another, the melancholic type is not even apt to deliberate at all. So, the uncontrolled person is like a city-state that passes all the indispensable decrees and has serious laws, but it makes no use of them" 25 .

Aristotle points to general features of the uncontrolled person. They act voluntarily, because they are aware of what they are doing and in a way for what goal. Thus, they are responsible for their acts. Furthermore, they do bad things. But they are not unjust, even though they do unjust things. For they lack vicious dispositions or acquired states of being able to act unjustly ${ }^{26}$. So, if they act unjustly, they will not do it deliberately. Indeed, they are not plotters ${ }^{27}$. He also maintains that they are not wicked, but only half-wicked

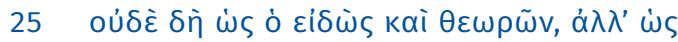

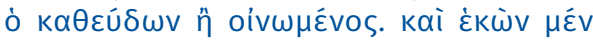

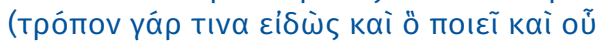

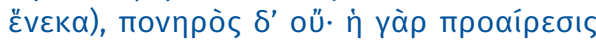

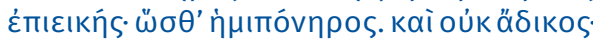
oú yà

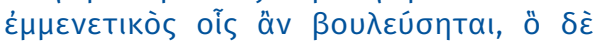

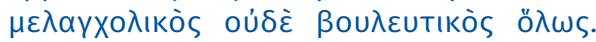

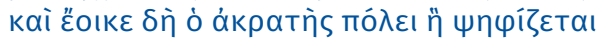

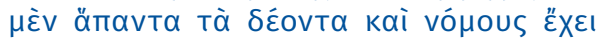

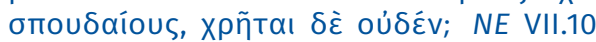
1152a14-21. See e.g., NE V.8 1135b24 or VII.8 1151a10-11. See e.g., NE V.8 1135b20. 


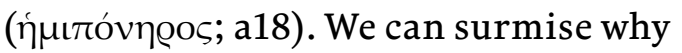
they are wicked from the expression "half-wicked" - their actions are bad. But why are they only half-wicked? Are they only half-wicked, because they lack vicious dispositions or acquired states of being able to do bad things? Possibly, but Aristotle insists that their

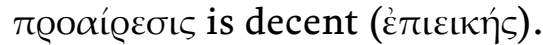

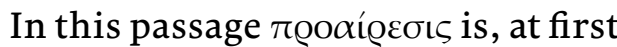
glance, a general goal. That is what the analogy with a state's laws refers to. For the uncontrolled person possesses knowledge about things they ought to never do in their life ${ }^{28}$. In other words, it seems that in this context Aristotle understands $\pi \varrho 0 \alpha i ́ \rho \varepsilon \sigma ı$ either as a general policy in life reflecting the person's understanding of eudaimonia or as a goal that leads us in pursuit of eudaimonia. After all, the uncontrolled person is like a city-state that has serious laws, but makes use of none of them. Indeed, they possess knowledge - the equivalent of serious laws - but they do not use it. For they are like being in a dream or

28 See e.g., NE IX.8 where Aristotle studies an aporia as to whether one ought to love oneself or someone else more (потєроv

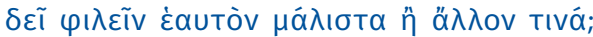
1168a28-29.). He shows that people criticize those who love themselves most and condemn them as "self-lover" in general (a29-30). And he stresses that they also accuse them of doing nothing apart from what concerns their own good (a31-33). So, those who make a value judgement in saying this, must possess knowledge that selfishness is a bad thing. But at the same time he underlines that such people or most of them do not use that knowledge and satisfy their appetites or non-rational aspect of their psuche at the expense of others (1168b15-22). And it ought to be added that they satisfy their non-rational aspect of their psuche at their own expense as rational beings. drunk when they are doing something. Thus, they surrender to desires of irrational psuche and do not follow their selves as rational beings. As a result of the lack of self-control, they listen to another aspect of themselves which does not fulfill, however, the function of an authoritative element in the structure of a human being. Nonetheless, Aristotle speaks about two different types of the uncontrolled person and the difference between them that can throw light on

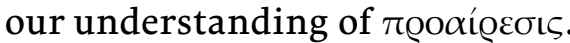

The lack of self-control ( $\dot{\alpha} \kappa \varrho \alpha \sigma i \alpha)$ is brought on by excessive desire in the case of the melancholic uncontrolled person. And for this reason, they do not deliberate at all. In consequence, they do not deliberate before acting. Thus, it is not possible to observe dissonance between the elaborated action plan and the actual course of action in their case. In fact, they do not take any action plan because of their impulsiveness. That is why they act on the spur of the moment ${ }^{29}$. Thus, in the matter of the melancholic uncontrolled person, when Aristotle says that the lack of self-control

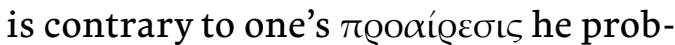

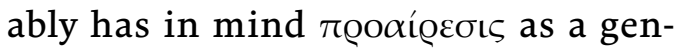

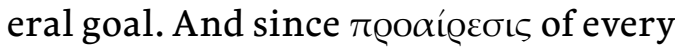
uncontrolled person is decent, we can assume that a general policy of life will

It should be noted that the swift uncontrolled person is also guided by emotion (see e.g. NE VII.7 1150b21-22). But they are different from the melancholic uncontrolled person for they deliberate to some extent, though, as a result of an impetuous desire, they are unable to complete it. See e.g., Charles (2011), p. 194. 
be decent in the case of the melancholic uncontrolled person.

The lack of self-control of the weak uncontrolled person is brought on by weak desires. But they are able to delib-

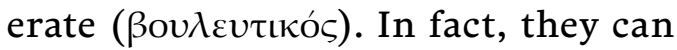
deliberate before taking action that ought to lead to realization of the designated goal. And they are capable of deliberating by using a "moving back" strategy. They can begin the calculation from the desired situation and finish it after they get to the initial situation. Thus, they commence with the goal and move backwards through means, until they arrive at the first cause, which is the last in the process of discovery. As a result, they discover the sequence of steps that they are to follow, where the last is the first one to take. Indeed, those who deliberate ought to investigate and to analyze as with a geometrical figure ${ }^{30}$. Nevertheless, they do not stand by what they have deliberated as a result of their susceptibility to relatively weak affective reactions $(\pi \alpha \dot{\theta} \theta \eta)^{31}$. Thus, they fail to be

30 "For the person who deliberates seems to investigate and to analyze [...], as he would in the case of a geometrical figure"

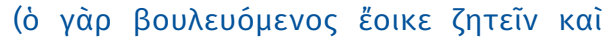

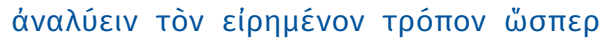

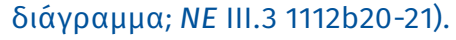

31 See e.g., NE VII.8 1151a1-5: “Among uncontrolled people those who are excitable are better than those who have [action] plan but do not stand by it. For the latter are overcome by less affective reaction and, unlike former, are not without prior deliberation. For the [latter] uncontrolled person is like those who are quickly drunk and after little wine, that

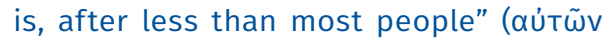

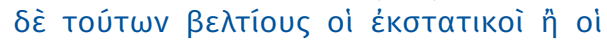

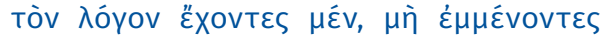

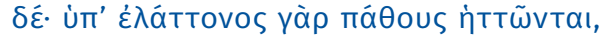

practical, though they finish their deliberation and reach the good result from the point of view of some goal held fixed in mind. In other words, they do not realize what they have planned because of their unstable character, that is to say, on account of their vulnerability to be affected by non-insistent $\pi \alpha \dot{\theta} \eta$. There are discrepancies between their action plan and what they actually do. Thus, the weak uncontrolled person is not so bad as to reach the level of internal integrity that would confirm that they focus their life on an evil goal and strive for it deliberately ${ }^{32}$. And when Aristotle says that the lack of self-control

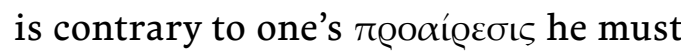
have something more in mind about

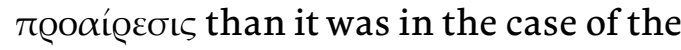
melancholic uncontrolled person. Since the weak uncontrolled person deliberates before taking action and reaches

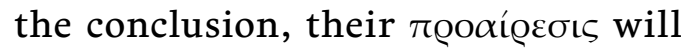
include a thoughtful undertaking or

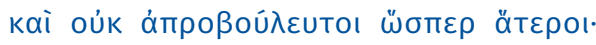

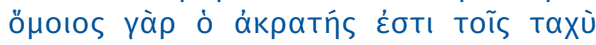

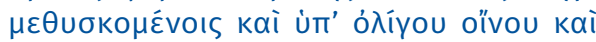

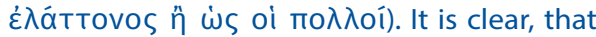
Aristotle has in mind the weak uncontrolled person when he declares that the latter are overcome by less pathē than most people.

32 For Aristotle, a truly bad person has a corrupt character (како́s, поvпрós). They are characterized by an inner harmony between rational and sensorical-orectical

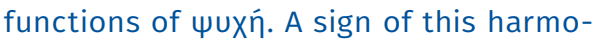
ny is a combination of character defects

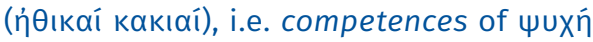
in sensorical-orectical function, and cunning ( $\pi \alpha v o u \rho y i \alpha)$, i.e., competence of reason in practical function. In fact, persons with a corrupt character are the master of evil, because they take actions based

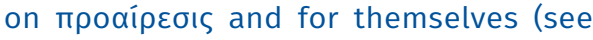
e.g., NE VII.7 1150a20). 
a preferential choice, depending on the

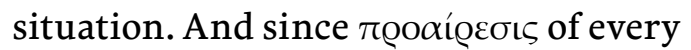
uncontrolled person is decent, we can assume that both a general policy of life and a thoughtful undertaking or preferential choice will be decent in the case of the weak uncontrolled person.

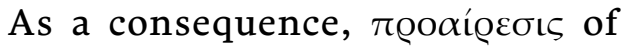
the melancholic uncontrolled person differs from rooxípeoıs of the weak uncontrolled person, although both

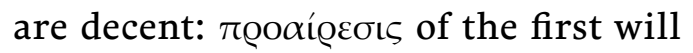
be limited to the setting of some goal

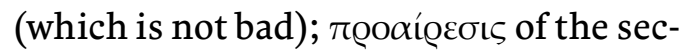
ond is something more, because deliberation is always a search for the means in light of having set down the goal. And since they conclude their deliberation, they will end it with a thoughtful undertaking or preferential choice.

Major characteristics of the weak uncontrolled person allow to assume

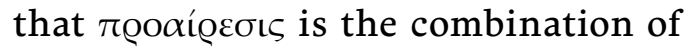
setting some goal and result of deliberation about how to achieve it. However, the deliberation is ended when it is completed by a thoughtful undertaking or preferential choice. Consequently,

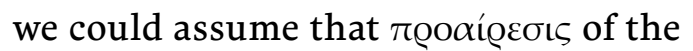
weak uncontrolled person includes such an undertaking or choice.

But it can be shown, against the background of the uncontrolled person's behavior, that could only apply to

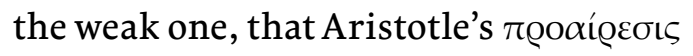
is not limited to a thoughtful undertaking or preferential choice. I am going

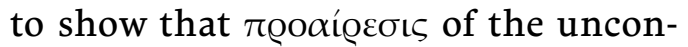
trolled person could include making the decision about proceeding with the realization of an action plan or even proceeding with the realization of the determined course of action, that is, taking on what has been determined by deliberation as chronologically first in the sequence of steps that lead to the achievement of the designated goal within the framework of the action plan developed. To show it, I will consider a certain example of behavior of the uncontrolled person.

We can imagine the uncontrolled person who realizes that they have an obesity problem. And we can assume that they deliberate before acting and consider possible action plans that would help them lose weight. For example, they take into account eating less sweets or jogging regularly, or following a slimming diet combined with physical activity ${ }^{33}$.

Let us assume that our uncontrolled person comes to the conclusion, as a result of their own deliberation, that the last possibility is the most promising. They are going to change their eating habits and start exercising regularly. However, they know little about diets and slimming exercises. So, they plan to seek advice of a dietitian and to consult with a personal trainer. Thus, they make the preferential choice of one

Thus, there will be a preferential choice in the proposed example. However, it is already known that a preferential choice does not have to be an element of

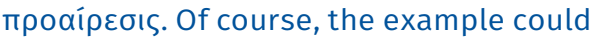
be modified, because we could assume that our uncontrolled person considers only one way to lose weight - for example, a slimming diet combined with physical activity - and ends the deliberation with the thoughtful undertaking and not with the preferential choice. 
course of action and decide to start the weight loss process from what is chronologically first in the sequence of steps that will lead to the achievement of the goal. In consequence, they try to register in a diet counseling center.

Hence, we can acknowledge that our uncontrolled person comes to the decent

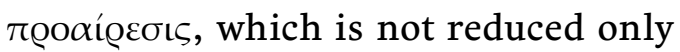
to the setting of the goal, that is, the losing weight (the goal that harmonizes with the general policy in life reflecting person's understanding of eudaimonia).

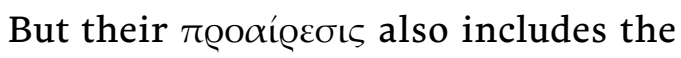
preferential choice, making the decision about proceeding to the realization of the action plan and even proceeding with the realization of the determined course of action.

Let us imagine that they could not register in a diet counseling because of an objective reason - it is, for instance, too late and the counseling center is already closed. Thus, they put off the beginning of the weight loss process until the next day. But the next day they do not keep their preferential choice and do not put what they decided to do the previous day into action - they do not proceed with fulfilling the action plan and do not register in a diet counseling center. But they abandon it not because it is beyond their power. It is rather caused by their characteristic instability - instead of reaching for a telephone, they grasp something sweet. Consequently,

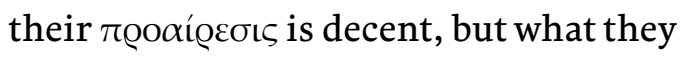
actually do does not follow their plans and even their decision about proceeding with realization of a preferentially chosen course of action. The result is not surprising, since the uncontrolled

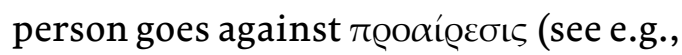
NE VII. 8 1151a7).

However, what type of uncontrolled person is in our example? No doubt, it is not the melancholic one, because they do not deliberate before acting. But is it the weak one? It might be, though it is not clear, since our uncontrolled person makes the decision about proceeding with a preferentially chosen course of action and even tries to take on what has been determined by deliberation as chronologically first in the sequence of steps that lead to the achievement of the designated goal. Nonetheless, if a person is not serious, there will be room for the lack of self-control, because it is caused by conflict within the desires of psuche between what is good and what is pleasant (EE VII.2 1237a7-9).

But it is significant that Aristotle

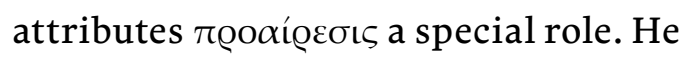
emphasizes that human characters are

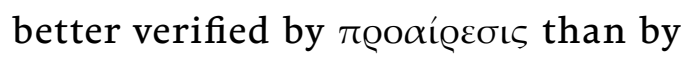
action (NE III.2 1111b6). This is why, we judge who someone is on the grounds

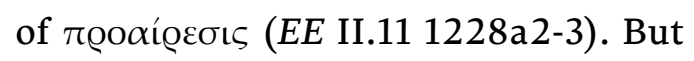
it is hard to accept that it is possible to say "they are the uncontrolled persons",

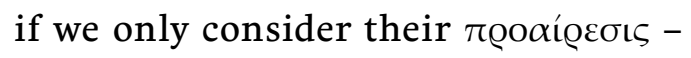

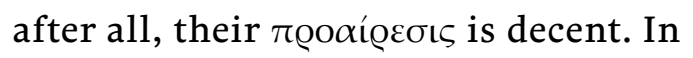
fact, we will be able to recognize that someone is the uncontrolled person if we take into account not only their general policy in life, but also their preferential choice or thoughtful undertaking and even their decision about proceeding with realization of designated goal in line with accepted action plan. Our example ultimately has a gap between 
what has happened before the potential beginning of realizing the designated goal and the actual beginning or implementation of that goal. When there is no such interval, it is difficult to determine what the scope of the activity of

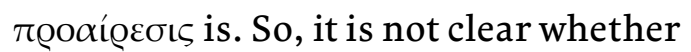

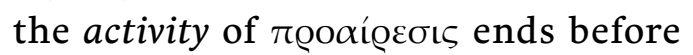
the action starts or whether it overlaps with the action. But the occurrence of the interval allows us to assume that

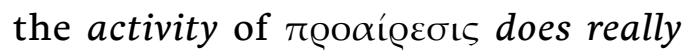
overlap with action and it is a specific moment of it, at least in the sense that

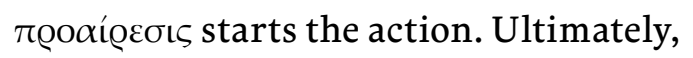
Aristotle underlines the point that

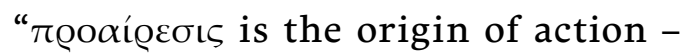
that from which the motion begins" 34 .

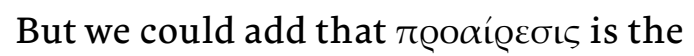
beginning to a higher degree than the moment of starting something, because

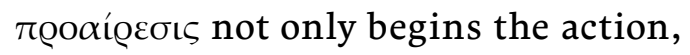
but it is also responsible for its course.

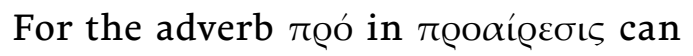
also point out that the agents pick out the act for the sake of a specific goal and take the position in front of it with the purpose of defending it, which means they aim to achieve the set goal to the best of their ability ${ }^{35}$.

Thus, the example seems to sug-

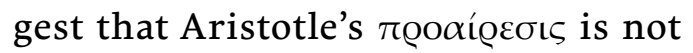

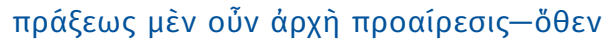

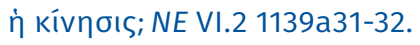

35 Thus, there is the question - whether the

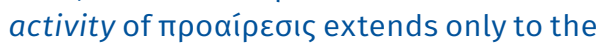
commencement of action or does it go on during the action and eventually ends with (successful) completion of it. As Broadie (1991), p. 212 notes, "a prohairetic response [...] is always [...] posed for possible revision". to be limited to setting a goal nor to a thoughtful undertaking nor to a preferential choice nor to the configuration of them. But it also seems to imply that

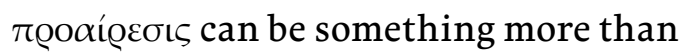
deciding about proceeding with realization of what has been thoughtfully undertaken or preferentially chosen. If such a view was wrong, it would be questionable that human characters

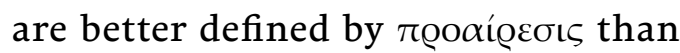
by action ${ }^{36}$. We would have a problem with distinguishing between the uncontrolled person and the decent

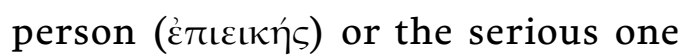

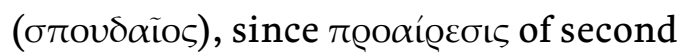
and third person is also decent. After all, Aristotle often identifies the decent person with serious one ${ }^{37}$.

\section{WHAT IS IPOA'IPEEIE FOR ARISTOTLE?}

I have suggested, at the end of section 1 ,

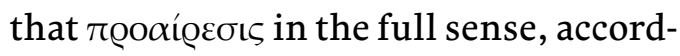
ing to Aristotle, ought to consist of: a] setting the goal; b] thoughtful undertaking or preferential choice, where both assume deliberation about how to achieve the designated goal but second requires deliberation on alternative courses of action; c] making the decision

It does not have to be understood that human characters are defined solely with reference to mpoaipeoıs, and the actions do not matter. Of course, they are important. But the actions themselves are insufficient (see e.g., NE V.8 1135b2-8). And there would be also a problem with distinction between the uncontrolled person and the truly bad person (see note 32 ) without taking into account

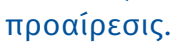

37 See e.g., NE IX.4 1166a12-33. 
about proceeding with a thoughtful undertaking or preferentially chosen course of action; d) proceeding with the realization of the determined course of action, that is, taking on what has been determined by deliberation as chronologically first in the sequence of steps that lead to the achievement of the designated goal; e] continuation of action that leads to the achievement of that

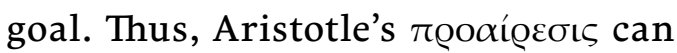
not be reduced to any of the moments included in points a], b], c] and d], nor to their arrangement.

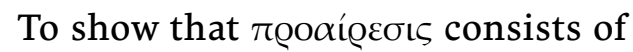
these five moments listed above, I have outlined features of the uncontrolled person, especially, of the melancholic and weak one, based on the passage NE VII.10 1152a15-24. Aristotle under-

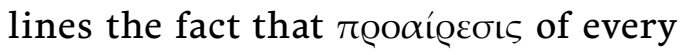
uncontrolled person is decent. Since the melancholic uncontrolled person does not deliberate before acting I have

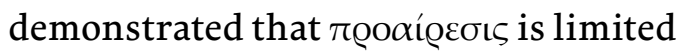
to a general policy of life in the case of them. But it turned out that rooxípeors of the weak uncontrolled person is something more, because they deliberate before taking action and conclude it, i.e., they end deliberation with the

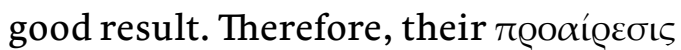
may include a thoughtful undertaking or a preferential choice, depending on situation. Indeed, major characteristics of the weak uncontrolled person has allowed to assume that rooxípeoıs of the weak uncontrolled person is the combination of setting some goal and a thoughtful undertaking or a preferential choice.
Next, I have considered an example of an uncontrolled behavior and against the background of it I have shown that

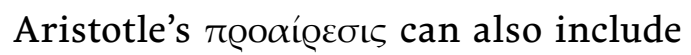
making the decision about proceeding to the realization of an action plan and even the attempt to take on what has been determined by deliberation as chronologically first in the sequence of steps that lead to achieve the goal within the framework of the action plan developed.

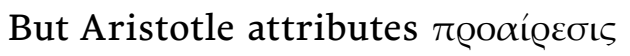
a special role, because he emphasizes that human characters are better veri-

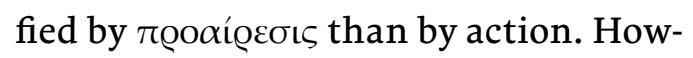
ever, the above-mentioned moments in points a], b], c] and d] as well as the configuration of them can belong to a certain kind of the uncontrolled

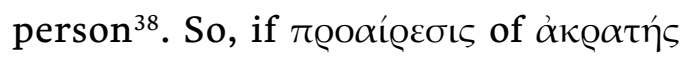
is decent, it will be a problem to distinguish between the character of the uncontrolled person and the character of the decent person or the serious one.

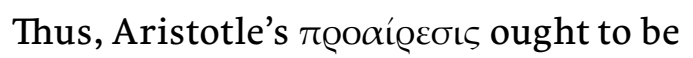
something more, if it is to be understood as a better verifier of human characters than actions.

According to the interpretation given at the end of section 2 "something

38 Of course, it is not the melancholic one, because they do not deliberate before acting. Nor it is the swift one, because they do not conclude the deliberation process. However, it remains the open question whether it is the weak one. Anyway, the uncontrolled person, in our example, tries to take on what has been determined by deliberation as chronologically first in the sequence of steps that lead to achieve the goal within the framework of the action plan developed. It may be that Aristotle's typology of the uncontrolled person is not complete. 
more" indicates that the activity of

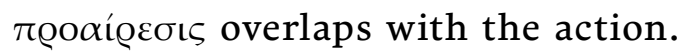
But the activity of it is not limited to the start of the action. The uncontrolled person, in our example, tries to begin the action with what is chronologically first in the sequence of steps which lead to reaching the set goal. Therefore,

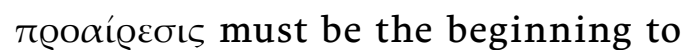
a higher degree than the moment of starting something. It not only begins the action, but it is also responsible for

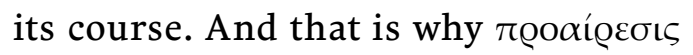
takes also into account the third understanding of the adverb roó, that is, "тœó" as standing in front of, and hence in defense of something. Indeed,

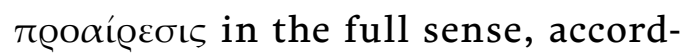
ing to Aristotle, must also include the continuation of action that leads to reaching the set goal. Thus, I think

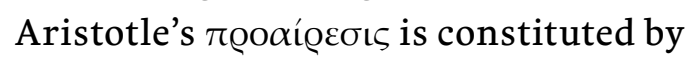
two elements: the orectical-deliberative element and the decisional-functional element ${ }^{39}$.

I was inspired by Formichelli's distinction

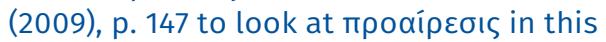
way. For he distinguishes dispositional

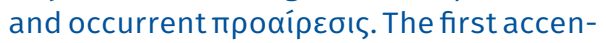
tuates the fact that we have deliberated about the specific situation we are facing, the second underlines the fact that the deliberation is effectively realized in action at that time. Furthermore, I am in debt to other commentators. As Kenny (in Aristotle (2011), p. 159) suggests, "carrying out a monastic vow or a New Year's resolution seems to be the closest thing in modern life to making an Aristotelian

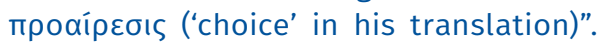
In turn, Price (2011), pp. 309-310 notes that

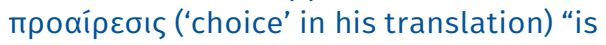
more than a desire: when the time is due it becomes an attempt, and (if all goes well) an action".

I can not fail to owe a debt of gratitude to Petrycy, Sebastian z Pilzna (old print [1608]; reprint [in:] Arystoteles [2011]:

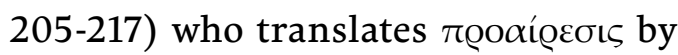
"choice or undertaking". In my opinion $^{40}$, the expression is not used accidentally. I think he tries to demonstrate

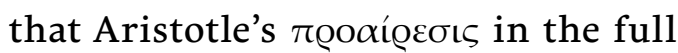
sense consists of: 1] "undertaking" in the sense of the set goal $\left.{ }^{41} ; 2\right]$ "own choice" in the sense of the preferential choice and decision about proceeding with the process of realization of the set goal in accordance with accepted action plan ${ }^{42}$; 3] "undertaking" in the sense of starting and continuation of the action that leads to the achievement of the set goal ${ }^{43}$. Thus, one can get the impression that Petrycy attempts to show that: i] Aristotle's

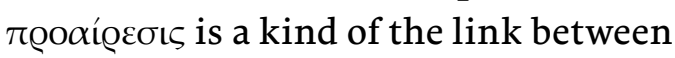
"choice" and "undertaking"; ii] "choice"

40 41 kinds of "choice": "common choice" and "own choice". The first is "taking something" caused by an affective reaction. Thus, it is not made on the basis of deliberation. The second is the immanent principle of the realization of thoughtful actions, and as a consequence it is made on the basis of deliberation. The person who makes own choice must be auctor agendi. Indeed, проаiрعбıs of such a person ought to consist of preferential choice and making the decision about proceeding with a preferentially chosen course of action. I present my interpretation of Petrycy's “own choice” in Smolak (ibidem), pp. 338-342.

43 See Petrycy (in Arystoteles (2011), p. 217) and my comments with respect to that in Smolak (ibidem), pp. 345-347. 
and undertaking" are specific aspects of

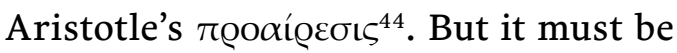
added that each one of "understanding" is in a different relation to "choice" of action plan. "Undertaking" in the sense of 1] is prior to it; "undertaking" in the sense of 2] is after it. Thus, "undertak-

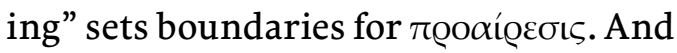
"choice" is made within these boundaries. But the boundary of "undertaking" in the sense of 2] is movable and it changes jointly with carrying out the action that aims to achieve the goal already laid down.

So, what are the constitutive elements of Aristotle's reoxíperıs in my interpretation? The orectical-deliberative element underlines the fact that

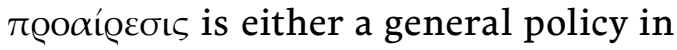
life reflecting the person's understanding of eudaimonia or a goal that leads us in pursuit of eudaimonia. But it also

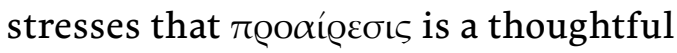
undertaking or a preferential choice. Thus both are preceded by deliberation, that is, by intellectual work that consists in searching for the best course of action and in discovering a reliable way to accomplish the designated goal. And such an examination is founded on the "moving back" strategy. According to it, what is at the end of the calculated way is the starting point of the process which leads to the achievement of that goal. Hence, within the orectical-deliberative

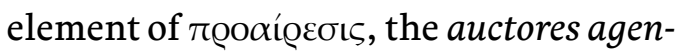
dus set the goal and come to a thoughtful

44 It is confirmed by Old-Polish language at the turn of the XVI century, because the conjunction "or" is not limited to an alternative. undertaking or to a choice of the best course of action, and both ought to lead to the achievement of the designated goal. Indeed, in several places Aristotle

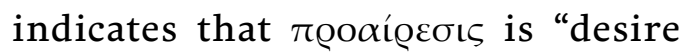

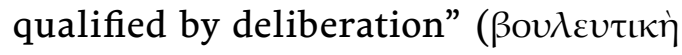

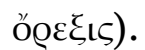

The decisional-functional element emphasizes that auctores agendus must: a] make the decision about proceeding with realization of what they have undertaken or chosen; b] proceed with realization of the action plan and continue on this path. Thus, the decision-functional element highlights two things.

Firstly, it accentuates that auctores agendus decide about proceeding with realization of what they have undertaken or chosen after deliberation and carry out what they have decided. It is important, because it may happen that to make a decision does not have to result in proceeding with action. However, it can not concern the situation in which an action is not started, because it is impossible to take such an action at a given moment or it is necessary to verify the accepted action plan as a result of the current difficulties or new data. It is rather about the situation in which auctores agendus do not act, even though it is up to them and failure to take an action undermines the opportunity to achieve the goal set by them. Thus, the decisional aspect of the decisional-functional element underlines the fact that the decision is fulfilled.

Secondly, it shows that roodí@erıs begins the action and defends it in its course. Thus, auctores agendus carry out the action which is chronologically first 
in the sequence of steps of the adopted action plan and they take responsibility for the realization of it. Indeed, they begin the realization of the action plan and also continue to implement it. Therefore, they guard against any kind of problems that could thwart the reaching the set goal. Of course, it is about problems that the avoidance is up to them. Thus, the functional aspect of the decisional-functional element underlines the fact that the sequential phases of the action plan are implemented.

The decisional-functional element complements the orectical-deliberative one. Hence, it seems that Aristotle's

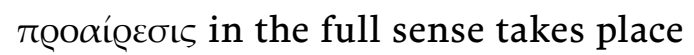
when auctores agendus carry out the line of action they have planned and de-

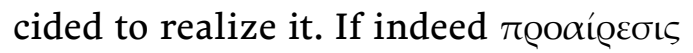
better determines human characters than actions, then it will be questiona-

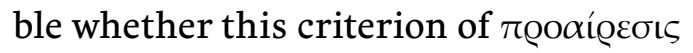
will be fulfilled without the decisional-functional element.

There are also additional advantages

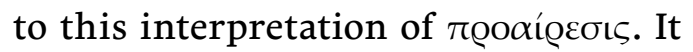
includes three understandings of the adverb r@ó - that is, preferential, temporal and as standing in front of, and hence in defense of something. Moreover, it makes

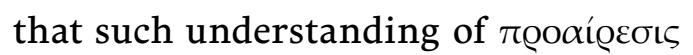
covers its various meanings.

\section{CONCLUSION}

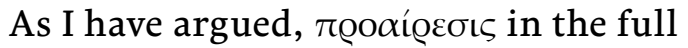
sense, according to Aristotle, consists of: a] setting the goal; b] thoughtful undertaking or preferential choice, where both assume deliberation about how to achieve the designated goal but second requires deliberation on alternative courses of action; c] making the decision about proceeding with a thoughtful undertaking or preferentially chosen course of action; d) proceeding with the realization of the determined course of action, that is, taking on what has been determined by deliberation as chronologically first in the sequence of steps which lead to the achievement of the designated goal; e] continuation of action that leads to the achievement of that

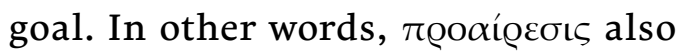
overlaps with the action and take care of its course.

This interpretation is not without foundation, because the points a], b], c] and d] are insufficient for a full assessment of human characters based

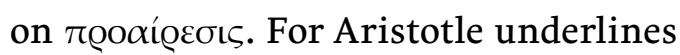

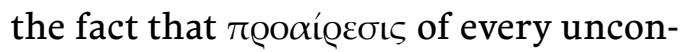
trolled person is decent. Meanwhile, the above-mentioned moments in points a],

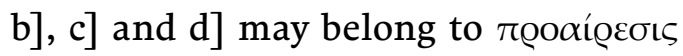
of the uncontrolled person: "setting the goal as a general policy of life" (a]) is common for all kinds of the uncontrolled person; "thoughtful undertaking or preferential choice" (b]) appears or can appear as moment of rooxípeors in the case of the weak uncontrolled person; "making the decision about proceeding with a thoughtful undertaking or preferentially chosen course of action and even trying to take on what has been determined by deliberation as chronologically first in the sequence of steps which lead to the achievement of the designated goal" (c] and d]) is present in the examined example of the uncontrolled behavior. But "continuation of action that 
leads to the achievement of the set goal in accordance with accepted action plan" (e]) requires the agent acts from a firm and unshakeable character (NE II.4 1105a30-33). If a person is not serious, there will be room for lack of self-control (EE VII.2 1237a7-8). Indeed, the serious person is the measure in the field of human affairs (NE IX.4 1166a12-13),

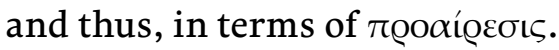

I would also like to remind the reader that I have mentioned, in Introduction,

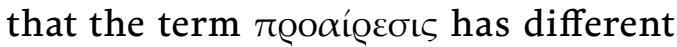
meanings and is practically untranslatable into modern languages, as are most crucial terms of classical Greek. But Aristotle often uses terms drawn from common language in the treatises and reinterprets them or assigns them technical meanings. That is also the case of

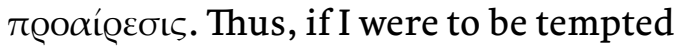

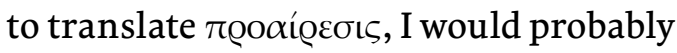
use the expression proposed by Petrycy, Sebastian z Pilzna, that is, "choice or undertaking", or I would limit myself to using the term "undertaking" 45 . For

See e.g., Rowe (in Aristotle (2002)) who renders проаірєбıs by "undertaking" in several places of NE. See e.g., I.1 1094a1-2: "Every sort of expert knowledge and every inquiry, and similarly every action

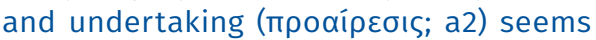
to seek some good"; I.4 1095a14-16: “[...] since every sort of knowledge, and every

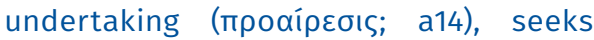
after some good, let us say what it is that we say political expertise seeks, and what the topmost of all achievable goods is"; 1.7 1097a20-21: “[...] in every

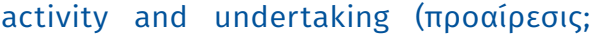
a21) it is the end" [it needs to be added that he uses "undertaking", when he translates tōn praktōn hapantōn (of all practical undertakings) in the next line].

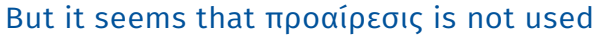
as technical term in these phrases. As "choice", in the sense of liberum arbitrium $^{46}$, does not have to be the key com-

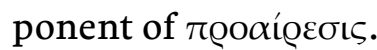

Furthermore, it can be added that "undertaking" means "przedsięwzięcie" in the Polish language. And it contains in itself three moments from the orectical-deliberative and decisional-functional elements, that is, deliberative, decisional and functional. Thus, "przedsięwzięcie" is: i] determined by deliberation; ii] taken on the basis of decision; and iii] carried out in accordance with action plan that is determined by deliberation.

Besides, the term "przedsięwzięcie" (przed-się-wzięcie) combines elements similar to those constituting

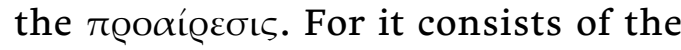
adverb "przed" - in English "before" which has inter alia preferential and temporal meaning, i.e., in principle, equivalent of the adverb roó, and of the noun "wzięcie" - in English "taking" - i.e., in principle, equivalent of the noun $\alpha i$ Qequs.

Brodie (in Aristotle (2002), p. 262) notes in commentary to I.1. 1094a2, Aristotle will give прохірєбıs a stricter meaning, that is, "decision" in the context of his theory of deliberate action in III.2-3. Furthermore, in the Introduction, she points out

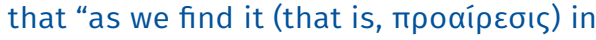
the non-philosophical writings of some of his (that is, Aristotle's) contemporaries is usually translated by 'undertaking' or "policy"' (ibidem), p. 42.

46 See Arendt (1978), p. 62 who claims that

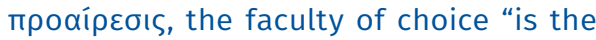
arbiter between several possibilities" and "In Latin, Aristotle's faculty of choice is liberum arbitrium". But it must be recalled that it is not necessary to take into account "to choose between alternatives" as a part of проаiрعбıs. 


\section{ABBREVIATIONS}

\author{
Aristotle \\ EE \\ Eudemian Ethics
}

$N E$

$M M$

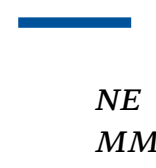

\author{
Nicomachean Ethics \\ Magna Moralia
}

\section{REFERENCES}

Adkins A.W.H. (1972). Moral Values and Political Behaviour in Ancient Greece. New York: Norton.

Aquinas, Thomas (1949). In decem libros Ethicorum Aristotelis ad Nicomachum expositio (cura et studio R.M. Spiazzi). Torrino: Marietti.

Arendt H. (1978). The Life of the Mind: Volume Two, Willing. New York; London: Harcourt Brace Jovanovich.

Aristote (1958). L'Éthique à Nicomaque (Introduction et Traduction par R.A. Gauthier et J.Y. Jolif). Tome I. Louvain : Publications Universitaires.

Aristote (1959). L'Éthique à Nicomaque (Introduction, Traduction et Commentaire par R.A. Gauthier et J.Y. Jolif). Tome II, partie 1. Louvain : Publication Universitaires.

Aristote (1959). Éthique à Nicomaque (Traduction avec Introduction par J. Tricot). Paris : Librairie Philosophique J. Vrin.

Aristotele (2012). Etica Eudemea (Introduzione, traduzione e note di M. Zanatta). Milano: Rizzoli.

Aristoteles (1960). Aristotelis Opera (ex recognition I. Bekkeri, edition altera quam curavit O. Gigon). Berolini: De Gruyter.

Aristoteles (1949). Ethicorum Aristotelis ad Nichomachum (S. Thomae Aquinatis, Cura et studio). Taurini: Marietti.
Aristoteles (1962). Eudemische Ethik (übersetzt von F. Dirlmeier). Berlin: Akademie-Verlag.

Aristotle (1962). Nicomachean Ethics (Translated with an Introduction and Notes by Martin Ostwald). Indianapolis: The Liberal Arts Press.

Aristotle (2000). Nicomachean Ethics (Translated and Edited by R. Crisp). Cambridge: Cambridge University Press.

Aristotle (2002). Nicomachean Ethics (Translation by $\mathrm{Ch}$. Rowe, Philosophical Introduction and Commentary by S. Broadie). Oxford: Oxford University Press.

Aristotle (2011). The Eudemian Ethics (Translated with an Introduction and Notes by A. Kenny). Oxford: Oxford University Press.

Aristotle (1985). The Nicomachean Ethics (Translated with Commentaries and Glossary by $\mathrm{T}$. Irwin). Indianapolis: Hackett Publishing Company.

Aristotle (1999). The Nicomachean Ethics (Translated with Introduction, Notes and Glossary by T. Irwin). $2^{\text {nd }}$ edition. Indianapolis: Hackett Publishing Company.

Aristotle (2009). The Nicomachean Ethics (Translated by D. Ross. Revised with an Introduction and Notes by L. Brown). Oxford: Oxford University Press. 
Arystoteles (1977). Etyka eudemejska (przekład, wstęp i przypisy, W. Wróblewski). Warszawa: PWN.

Arystoteles (1956). Etyka nikomachejska (przekład, opracowanie i wstęp, D. Gromska). Warszawa: PWN.

Arystoteles (2011). Etyka nikomachejska (przekład, Sebastian Petrycy z Pilzna). Warszawa: Hachette.

Bobonich Ch. (2006). „Aristotle's Ethical Treatises“. In: R. Kraut (ed.), The Blackwell Guide to Aristotle's Nicomachean Ethics, Malden: Blackwell, pp. 12-36.

Bostock D. (2000). Aristotle's Ethics. Oxford: Oxford University Press.

Broadie S. (1991). Ethics with Aristotle. New York: Oxford University Press.

Charles D. (2011). „Akrasia: the Rest of the Story?,. In: M. Pakaluk, G. Pearson (eds.), Moral Psychology and Human Action in Aristotle, Oxford: Oxford University Press, pp. 187-209.

Düring I. (1966). Aristotelis. Heidelberg: Carl Winter.

Formichelli M.A. (2009). Aristotle's Theory of Prohairesis and Its Significance for Accounts of Human Action and Practical Reasoning. Boston College Electronic Thesis or Dissertation, Boston College University Libraries, http://hdl.handle. net/2345/729.

Jaeger W. (1923). Aristoteles. Grundlegung einer Geschichte seiner Entwicklung. Berlin: Weidmannsche Buchhandlung.
Joachim H.H. (1955). Aristotle: The Nicomachean Ethics (ed. D.A Rees). Oxford: Clarendon Press.

Kenny A. (1978). The Aristotelian Ethics. Oxford: Clarendon Press.

Kenny A. (1979). Aristotle's Philosophy of Action. New Haven CT: Yale University Press.

Nielsen K.M. (2011). "Deliberation as Inquiry: Aristotle's Aletrnative to the Presumption of Open Alternatives". Philosophical Review 120(3), pp. 383-421.

Petrycy, Sebastian z Pilzna (1608). Ethyki Arystotelesowey, To iest Iako się każdy ma na swiecie rzadzić, Z Dokladem Ksiag Dziesięciorga Pierwsza Częsc, W Ktorey Pięciorgo Ksiag: Pożyteczne każdemu nie tylko do poczciwego na świecie życia, ale też aby człowiek każdy wiedzial, ktorym sposobem ma przychodzić do nawiętbego na świecie błogosławieństwa y sczęścia: Przydatne sa do każdego Rozdziału Przestrogi, które trudniejsze rzeczy krótko wykładają: Przydatki też są położone na końcu Ksiąg każdych, dla gruntownieybego rzeczy w Księgach tknionych wyrozumienia, częścia dla zaostrzenia dowicipow buynieybych, potrzebne Przez Doktora Sebastiana Petricego Medyka. Drukarnia Macieia Iędrzeiowczyka.

Price A.W. (2011). Virtue and Reason in Plato and Aristotle. Oxford: Clarendon Press.

Schleiermacher F. (1835). Über die ethischen Werks des Aristoteles. Berlin.

Sorabji R. (1980). Necessity, Cause and Blame. Perspectives on Aristotle's Theory. Ithaca NY: Cornell University Press. 